\title{
Prognostic Factors for the Occurrence of Post-Operative Shoulder Stiffness After Arthroscopic Rotator Cuff Repair: A Systematic Review
}

Thomas Stojanov ( $\sim$ Thomas.stojanov@usb.ch )

University Hospital of Basel

Linda Modler

University Hospital of Basel

Andreas M. Müller

University Hospital of Basel

Soheila Aghlmandi

University Hospital Basel and University of Basel

Christian Appenzeller-Herzog

University of Basel

Rafael Loucas

University of Zurich

Marios Loucas

University of Zurich

Laurent Audigé

Schulthess Clinic

\section{Research Article}

Keywords: risk factors, prognostic factors, arthroscopy, rotator cuff tear, shoulder stiffness

Posted Date: July 12th, 2021

DOI: https://doi.org/10.21203/rs.3.rs-672350/v1

License: @) (7) This work is licensed under a Creative Commons Attribution 4.0 International License. Read Full License 


\section{Abstract}

\section{Background}

Post-operative shoulder stiffness (POSS) is one of the most frequent complications after arthroscopic rotator cuff repair (ARCR). Factors specifying clinical prediction models for the occurrence of POSS should rely on the literature and expert assessment. Our objective was to map prognostic factors for the occurrence of POSS in patients after an ARCR.

\section{Methods}

Longitudinal studies of ARCR reporting prognostic factors for the occurrence of POSS with an endpoint of at least 6 months were included. We systematically searched Embase, Medline, and Scopus for articles published between January 1, 2014 and February 12, 2020 and screened cited and citing literature of eligible records and identified reviews. The risk of bias of included studies and the quality of evidence were assessed using the Quality in Prognosis Studies tool and an adapted Grading of Recommendations, Assessment, Development and Evaluations framework. A database was implemented to report the results of individual studies. The review was registered on PROSPERO (CRD42020199257).

\section{Results}

Seven cohort studies including 23257 patients were included after screening 5013 records. POSS prevalence ranged from $0.51 \%$ to $8.75 \%$ with an endpoint ranging from 6 to 24 months. Due to scarcity of data, no meta-analysis could be performed. Overall risk of bias and quality of evidence was deemed high and low or very low, respectively. Twenty-two potential prognostic factors were identified. Increased age and male sex emerged as protective factors against POSS. Additional factors were reported but do require further analyses to determine their prognostic value.

\section{Discussion}

Available evidence pointed to male sex and increased age as probable protective factors against POSS after ARCR. To establish a reliable pre-specified set of factors for clinical prediction models, our review results require complementation with an expert's opinion.

\section{Three Take-home Messages:}

1: Male sex and increased age are probable prognostic factors decreasing the risk of POSS. BMI, smoking status, and hypothyroidism require further analyses to be confirmed as prognostic factors.

2: Low methodological quality of included studies impaired us from drawing clear conclusions.

3: Further clinical prediction model development and prognostic factor analyses regarding post-operative shoulder stiffness and relying on prospective and well-designed cohort studies should be conducted.

\section{Background}

Patients expect the highest level of safety and effectiveness when they undergo elective orthopedic surgery. Satisfied preoperative expectations as to safety and effectiveness of an orthopedic procedure are among the main determinants of patient satisfaction post-operatively [1].

Patient safety in surgery involves issues related to the quality of care, the occurrence of adverse events (AE), and their management. Published rates of AEs in orthopedics are variable [2,3]. Following arthroscopic rotator cuff repair (ARCR), recurrence of rotator cuff defects, worsening or persisting pain or post-operative shoulder stiffness (POSS) are the most prevalent AEs. POSS, which affects $5-10 \%$ of patients [4], may remain mild, but can also cause severe functional disability in everyday activities, requiring prolonged rehabilitation and, in severe cases, further surgical intervention [5]. 
Accurate and reliable documentation of prospective cohorts is a prerequisite for providing evidence regarding post-operative outcomes of ARCR including POSS. These data can be used for the development of clinical prediction models (CPM) allowing individual outcome predictions. Choice of the factors specifying CPM should rely on prior comprehensive systematic reviews and expert assessment [6]. The current literature reported limitations in the published evidence related to prognostic factors for structural or clinical outcomes of ARCR [2,7-12]. We therefore set out to systematically review the literature to synthesize the evidence on prognostic factors for POSS after ARCR. Our objective was to map prognostic factors for the occurrence of POSS in patients after ARCR.

\section{Methods}

This systematic review was written according to Preferred Reporting Items for Systematic Review and Meta-Analysis (PRISMA) reporting guidelines [13], and registered in PROSPERO on August 24, 2020 (registration number: CRD42020199257).

\section{Eligibility criteria}

Longitudinal studies of patients with rotator cuff tear treated by primary ARCR were searched. We selected studies reporting on at least one prognostic factor for the occurrence of POSS, whatever definitions were used. Studies written in another language than English, French, or German, with a clinical follow-up of less than 6 months, on patients with irreparable tears, or revision operations were excluded.

\section{Information sources and search algorithm}

The search strategies were developed by two information specialists (including CAH) and peer-reviewed by a third information specialist. Text word synonyms and database-specific subject headings for rotator cuff tear and arthroscopic repair surgery were used to search the electronic databases Embase (Elsevier), Medline (Ovid), and Scopus (Elsevier) without language restriction but excluding conference abstracts (Additional file 1; last search February 12, 2020). Since surgical rotator cuff repairs substantially evolved around 2013/2014 [14] and recent systematic reviews already summarized the evidence related to prognostic factors for ARCR patient outcomes [2, 7-12], the search results were limited to records published in 2014 and onwards. The final search string was written and optimized in embase.com syntax and translated for the other databases using a macro [15] and the systematic review accelerator [16], respectively. To complement the results of direct database searching, we screened the bibliographic references of all included articles as well as the citing articles of those that were indexed in Scopus or the Web of Science (November 23,2020). The bibliographic references of identified systematic and narrative reviews on ARCR were also screened as an additional source. References were exported to Endnote X9 (Clarivate Analytics Philadelphia, PA USA) and deduplicated using the Bramer method [17].

\section{Study selection and data collection}

The search results were screened independently by two reviewers (LM and TS) based on reference titles and abstracts. References that were not excluded by agreement were then retrieved in full text and assessed independently for eligibility (LM and TS).

Two review authors (either LM, TS, ML, or RL) independently extracted data from selected studies following an adapted version of the Checklist for Critical Appraisal and data extraction for systematic reviews of prediction modeling studies for prognostic factors (CHARMS-PF) [18]. Extraction items are listed in Additional file 2.

\section{Risk of bias assessment}

The risk of bias of included studies was assessed using the Quality in Prognosis Studies (QUIPS) tool [19]. We agreed on a series of pre-defined key characteristics for the description of the population (tear pattern and tear etiology), the intervention (number of surgeons involved and repair technique), and the rehabilitation protocol (duration of post-operative immobilization) to guide our judgment when assessing the risk of bias for the Study participation item. The studies reporting only a part of 
univariable or bivariable effect estimates were all considered as having a high risk of bias regarding the statistical analysis and reporting item.

Any disagreements in any step of the review process were resolved by consensus or involved arbitration by the last author (LA).

\section{Summary measures and synthesis of results}

Effect estimates were reported as described in individual studies. Whenever possible, odds ratios (OR) and their confidence intervals were calculated (i.e. the number of events and non-events per variable and outcome group were reported). When needed, effect estimates were inverted by applying a simple inverse function to help us in interpreting the results of a given factor. A meta-analysis was performed if more than three studies assessed the association between POSS and the same prognostic factor estimate.

\section{Quality of evidence}

As suggested by Riley et al. [20], we graded the quality of evidence related to prognostic factors using an adaptation of the GRADE framework [21]. This instrument contained six domains contributing to low quality including the phase of investigation (confirmatory or explanatory), study limitations, inconsistency across studies, indirectness (according to the review question), within (sample size, number of events per outcome) and across (number of studies and number of participants per study) study imprecision, and publication bias. Two additional domains were considered for higher quality of evidence: presence of moderate or large effect and exposure-gradient response.

\section{Prognostic factor terminology}

When extracting data, a prognostic factor was understood as "any variable that, among people with a given health condition (i.e. a start point), is associated with (the risk of) a subsequent clinical outcome (i.e. an endpoint). Different values (or categories) of a prognostic factor are associated with a better or worse prognosis." [20]

In the present review, we defined a factor as probably prognostic when, overall, authors of individual studies reported the same direction of association with at least a low quality of evidence (as ranked with the GRADE framework [21]).

\section{Results}

\section{Study selection}

From 5013 initial records screened on titles and abstracts, 573 full-text articles were assessed for eligibility. After full-text screening, five studies were eligible for inclusion [22-26]. Backward and forward citation tracking on these as well as on seven [27-33] topical reviews that were flagged during title/abstract screening identified eight additional potentially eligible records, two of which were included in the review [34,35]. Most of the excluded full-text articles did not report the occurrence of POSS $(N=293)$ or did not conduct a prognostic factor analysis $(N=120)$. Study selection is summarized in Fig. 1.

\section{Study characteristics}

All the studies were published between 2016 and 2020 and involved 23257 patients across five countries (United States of America [23, 24], South Korea [25, 26], Australia [22], Japan [35], and Italy [34]).

\section{Participants}

The authors of three studies included patients with isolated supraspinatus rotator cuff tears [22, 26, 34]. In the other four studies, the type of tears was not reported [23-25,35] (Table 1). Whereas one study included both degenerative and traumatic tears [22], another study included only degenerative tears [34]. In the other studies, the tear etiology was not precisely described [23-26, 35]. Patients with concomitant shoulder pathologies such as acromioclavicular arthritis, biceps pathologies, or shoulder instability requiring treatments were excluded in four studies [24-26, 34]. 


\section{Intervention}

In five studies, authors reported outcome results for a single surgeon $[22,25,26,34,35]$. In the two remaining studies, the number of surgeons involved was not stated $[23,24]$ (Table 2). Either single-row $[22,34]$ or suture-bridge $[25,35]$ repair techniques were used. In the three remaining studies, the repair technique was not reported $[23,24,26]$. 
Table 1

characteristics of included studies

\begin{tabular}{|c|c|c|c|c|c|c|c|}
\hline Author & Year & Country & Design & $\begin{array}{l}\text { Number } \\
\text { of } \\
\text { patients }\end{array}$ & Population & Intervention & Rehabilitation protocol \\
\hline Cho, C.H. & 2015 & $\begin{array}{l}\text { South } \\
\text { Korea }\end{array}$ & $P$ & 80 & $\begin{array}{l}\text { Patients with types of } \\
\text { tear patterns and } \\
\text { etiology that were not } \\
\text { precisely described; } \\
\text { Exclusion of patients } \\
\text { with workers } \\
\text { compensation claims, } \\
\text { or requiring additional } \\
\text { procedures (AC arthritis, } \\
\text { biceps pathologies) }\end{array}$ & $\begin{array}{l}\text { One } \\
\text { surgeon } \\
\text { involved, } \\
\text { repair } \\
\text { technique } \\
\text { not } \\
\text { precisely } \\
\text { described }\end{array}$ & $\begin{array}{l}\text { Post-operative } \\
\text { immobilization not } \\
\text { precisely described. } \\
\text { Active range of motion } \\
\text { started at } 6 \text { weeks } \\
\text { after surgery. } \\
\text { Strengthening } \\
\text { exercises started after } \\
3 \text { months, and sport } \\
\text { activities from } 6 \\
\text { months }\end{array}$ \\
\hline Cho, N.S. & 2015 & $\begin{array}{l}\text { South } \\
\text { Korea }\end{array}$ & $\mathrm{R}$ & 335 & $\begin{array}{l}\text { Patients with full- } \\
\text { thickness supraspinatus } \\
\text { tears, with fatty } \\
\text { infiltration }<2 \text {, etiology } \\
\text { not precisely described; } \\
\text { Exclusion of patients } \\
\text { with workers } \\
\text { compensation claims, } \\
\text { or requiring additional } \\
\text { procedures (AC arthritis, } \\
\text { biceps pathologies) }\end{array}$ & $\begin{array}{l}\text { One } \\
\text { surgeon } \\
\text { involved, } \\
\text { suture- } \\
\text { bridge } \\
\text { technique } \\
\text { used }\end{array}$ & $\begin{array}{l}\text { Post-operative } \\
\text { immobilization not } \\
\text { precisely described. } \\
\text { Active range of motion } \\
\text { started at } 6 \text { weeks } \\
\text { after surgery. } \\
\text { Strengthening } \\
\text { exercises started after } \\
6 \text { weeks, and sport } \\
\text { activities from } 6 \\
\text { months }\end{array}$ \\
\hline Tan, M. & 2016 & Australia & $\mathrm{R}$ & 1300 & $\begin{array}{l}\text { Patients with } \\
\text { supraspinatus tears, } \\
\text { and both degenerative } \\
\text { or traumatic tears; No } \\
\text { specific exclusion } \\
\text { criteria }\end{array}$ & $\begin{array}{l}\text { One } \\
\text { surgeon } \\
\text { involved, } \\
\text { single-row } \\
\text { repair } \\
\text { technique } \\
\text { used }\end{array}$ & $\begin{array}{l}\text { Post-operative } \\
\text { immobilization in a } \\
\text { sling with a small } \\
\text { abduction pillow. } \\
\text { Active range of motion } \\
\text { started at } 6 \text { weeks } \\
\text { after surgery. } \\
\text { Strengthening } \\
\text { exercises started after } \\
3 \text { months, and sport } \\
\text { activities from } 6 \\
\text { months }\end{array}$ \\
\hline $\begin{array}{l}\text { Burrus, } \\
\text { M.T }\end{array}$ & 2019 & U.S.A. & $\mathrm{R}$ & 19229 & $\begin{array}{l}\text { Patients with types of } \\
\text { tear patterns and } \\
\text { etiology that were not } \\
\text { precisely described; } \\
\text { Exclusion of patients } \\
\text { requiring additional } \\
\text { procedures (AC arthritis, } \\
\text { biceps pathologies, and } \\
\text { instability) }\end{array}$ & $\begin{array}{l}\text { Number of } \\
\text { surgeons } \\
\text { involved } \\
\text { and repair } \\
\text { technique } \\
\text { not } \\
\text { precisely } \\
\text { described }\end{array}$ & $\begin{array}{l}\text { Rehabilitation } \\
\text { procedure not } \\
\text { precisely described }\end{array}$ \\
\hline $\begin{array}{l}\text { Harada, } \\
\text { G.K. }\end{array}$ & 2019 & U.S.A. & $\mathrm{R}$ & 1881 & $\begin{array}{l}\text { Patients with types of } \\
\text { tear patterns and } \\
\text { etiology that were not } \\
\text { precisely described; No } \\
\text { specific exclusion } \\
\text { criteria }\end{array}$ & $\begin{array}{l}\text { Number of } \\
\text { surgeons } \\
\text { involved } \\
\text { and repair } \\
\text { technique } \\
\text { not } \\
\text { precisely } \\
\text { described }\end{array}$ & $\begin{array}{l}\text { Rehabilitation } \\
\text { procedure not } \\
\text { precisely described }\end{array}$ \\
\hline
\end{tabular}

$\mathrm{AC}=$ Acromioclavicular, $\mathrm{P}=$ prospective, $\mathrm{R}=$ retrospective, U.S.A. = United States of America 


\begin{tabular}{|c|c|c|c|c|c|c|c|}
\hline Author & Year & Country & Design & $\begin{array}{l}\text { Number } \\
\text { of } \\
\text { patients }\end{array}$ & Population & Intervention & Rehabilitation protocol \\
\hline Cucchi, D. & 2020 & Italy & $\mathrm{P}$ & 237 & $\begin{array}{l}\text { Patients with } \\
\text { degenerative } \\
\text { supraspinatus tears; } \\
\text { Exclusion of patients } \\
\text { requiring additional } \\
\text { procedures (AC arthritis, } \\
\text { biceps pathologies, and } \\
\text { instability) }\end{array}$ & $\begin{array}{l}\text { One } \\
\text { surgeon } \\
\text { involved, } \\
\text { single-row } \\
\text { repair } \\
\text { technique } \\
\text { used }\end{array}$ & $\begin{array}{l}\text { Post-operative } \\
\text { immobilization in a } \\
\text { sling. Passive range of } \\
\text { motion started after } 1 \\
\text { month. Active range of } \\
\text { motion started after } \\
\text { reaching full passive } \\
\text { range of motion. } \\
\text { Strengthening } \\
\text { exercises started after } \\
3 \text { months. Start of } \\
\text { usual sport activities } \\
\text { not precisely } \\
\text { described }\end{array}$ \\
\hline $\begin{array}{l}\text { Takahashi, } \\
\text { R. }\end{array}$ & 2020 & Japan & $\mathrm{R}$ & 195 & $\begin{array}{l}\text { Patients with types of } \\
\text { tear patterns and } \\
\text { etiology that were not } \\
\text { precisely described; } \\
\text { Exclusion of patients } \\
\text { requiring additional } \\
\text { procedures (instability) }\end{array}$ & $\begin{array}{l}\text { One } \\
\text { surgeon } \\
\text { involved, } \\
\text { suture- } \\
\text { bridged } \\
\text { repair } \\
\text { technique } \\
\text { used }\end{array}$ & $\begin{array}{l}\text { Post-operative } \\
\text { immobilization in an } \\
\text { abduction brace for } 4 \\
\text { weeks. Passive range } \\
\text { of motion started } \\
\text { directly after the } \\
\text { operation. Active } \\
\text { range of motion } \\
\text { started after } 4 \text { weeks. } \\
\text { Strengthening } \\
\text { exercises started after } \\
6 \text { weeks. Start of } \\
\text { usual sport activities } \\
\text { after } 6 \text { months }\end{array}$ \\
\hline
\end{tabular}


Table 2

outcomes and statistical analyses of included studies

\begin{tabular}{|c|c|c|c|c|c|c|}
\hline Author & Year & POSS definition & $\begin{array}{l}\text { Time } \\
\text { point } \\
\text { (months) }\end{array}$ & Type & Value $^{a}$ & $\begin{array}{l}\text { Statistical } \\
\text { analysis } \\
\text { methods }\end{array}$ \\
\hline Tan, M. & 2016 & $\begin{array}{l}\text { Part of a scale (L'Insalata } \\
\text { questionnaire) describing perceived } \\
\text { shoulder stiffness [36] }\end{array}$ & 6 & Categorized $^{\mu}$ & - & $\begin{array}{l}\text { Bivariable } \\
\text { analysis } \\
\text { using a 2- } \\
\text { way between } \\
\text { subject } \\
\text { analysis of } \\
\text { variance } \\
\text { without } \\
\text { considering } \\
\text { cofounding }\end{array}$ \\
\hline Cucchi, D. & 2020 & $\begin{array}{l}\text { Part of range of motion parameters. } \\
\text { Defined as forward flexion }<100^{\circ} \text {, or } \\
\text { external rotation with arm at side }<10^{\circ} \text {, } \\
\text { or external rotation with arm in } 90^{\circ} \text { of } \\
\text { abduction }<30^{\circ}\end{array}$ & $3-6$ & Dichotomous & $\begin{array}{l}19 / 237 \\
(8.01 \%)\end{array}$ & $\begin{array}{l}\text { Multivariable } \\
\text { analysis } \\
\text { using a } \\
\text { logistic } \\
\text { regression } \\
\text { model } \\
\text { specified } \\
\text { with factors } \\
\text { included if } \\
\text { their } \\
\text { influence } \\
\text { was } \\
\text { significant in } \\
\text { the } \\
\text { preliminary } \\
\text { univariable } \\
\text { analysis }\end{array}$ \\
\hline $\begin{array}{l}\text { Takahashi, } \\
\text { R. }\end{array}$ & 2020 & $\begin{array}{l}\text { Part of range of motion parameters. } \\
\text { Defined as forward flexion < or equal } \\
100^{\circ} \text {, and external rotation with arm at } \\
\text { side < or equal to } 10^{\circ} \text { and internal } \\
\text { rotation < or equal to L5 }\end{array}$ & 6 & Dichotomous & $\begin{array}{l}1 / 195 \\
(0.51 \%)\end{array}$ & $\begin{array}{l}\text { Univariable } \\
\text { analysis } \\
\text { using } \\
\text { Fisher's } \\
\text { exact test } \\
\text { without } \\
\text { considering } \\
\text { confounding }\end{array}$ \\
\hline $\begin{array}{l}\text { Burrus, } \\
\text { M.T }\end{array}$ & 2019 & $\begin{array}{l}\text { Requiring manipulation under } \\
\text { anesthesia or a lysis of adhesion }\end{array}$ & 9 & Dichotomous & $\begin{array}{l}232 / 19229 \\
(1.21 \%)\end{array}$ & $\begin{array}{l}\text { Multivariable } \\
\text { database } \\
\text { analysis } \\
\text { using a } \\
\text { logistic } \\
\text { regression } \\
\text { model } \\
\text { specified } \\
\text { with risk } \\
\text { factors } \\
\text { identified in } \\
\text { the literature } \\
\text { and } \\
\text { controlling } \\
\text { for several } \\
\text { other } \\
\text { cofounders }\end{array}$ \\
\hline
\end{tabular}

L3 = Third lumbar vertebra, L5 = Fifth lumbar vertebra, POSS = Post-operative shoulder stiffness,

a: for dichotomized outcomes, the value for the outcome was the prevalence at the given timepoint (i.e. the number of events over the number of patients analyzed in the study), $\mu$ : categories for L'Insalata questionnaire [36]: $0=$ none, $1=$ little, 2 = moderately, 3 = quite, 4 = very 


\begin{tabular}{|c|c|c|c|c|c|c|}
\hline Author & Year & POSS definition & $\begin{array}{l}\text { Time } \\
\text { point } \\
\text { (months) }\end{array}$ & Type & Value $^{a}$ & $\begin{array}{l}\text { Statistical } \\
\text { analysis } \\
\text { methods }\end{array}$ \\
\hline Cho, C.H. & 2015 & $\begin{array}{l}\text { Part of range of motion parameters. } \\
\text { Defined as forward flexion of }<120^{\circ} \\
\text { and external rotation with arm at side }< \\
30^{\circ}\end{array}$ & 12 & Dichotomous & $\begin{array}{l}7 / 80 \\
(8.75 \%)\end{array}$ & $\begin{array}{l}\text { Univariable } \\
\text { analysis } \\
\text { using a chi- } \\
\text { square test } \\
\text { without } \\
\text { considering } \\
\text { confounding }\end{array}$ \\
\hline $\begin{array}{l}\text { Harada, } \\
\text { G.K. }\end{array}$ & 2019 & $\begin{array}{l}\text { Requiring manipulation under } \\
\text { anesthesia, such as capsular } \\
\text { contracture release, shoulder joint, or } \\
\text { arthroscopy }\end{array}$ & 12 & Dichotomous & $\begin{array}{l}73 / 1881 \\
(3.88 \%)\end{array}$ & $\begin{array}{l}\text { Multivariable } \\
\text { database } \\
\text { analysis } \\
\text { using a } \\
\text { logistic } \\
\text { regression } \\
\text { model } \\
\text { specified } \\
\text { with factors } \\
\text { chosen by } \\
\text { the authors }\end{array}$ \\
\hline Cho, N.S. & 2015 & $\begin{array}{l}\text { Part of range of motion parameters. } \\
\text { Defined as forward flexion }<120^{\circ} \text { and } \\
\text { external rotation with arm at side }<30^{\circ} \\
\text { and internal rotation }<L 3\end{array}$ & 24 & Dichotomous & $\begin{array}{l}21 / 335 \\
(6.27 \%)\end{array}$ & $\begin{array}{l}\text { Univariable } \\
\text { analysis } \\
\text { using a chi- } \\
\text { square test } \\
\text { without } \\
\text { considering } \\
\text { confounding }\end{array}$ \\
\hline $\begin{array}{l}\text { L3 = Third } \\
\text { a: for dich } \\
\text { events ove } \\
2=\text { moder }\end{array}$ & $\begin{array}{l}\text { ibar ve } \\
\text { nized } \\
\text { e num } \\
y, 3=q\end{array}$ & $\begin{array}{l}\text { ebra, L5 = Fifth lumbar vertebra, POSS = } \\
\text { utcomes, the value for the outcome was } t \\
\text { er of patients analyzed in the study), } \mu \text { : ca } \\
\text { ite, } 4=\text { very }\end{array}$ & $\begin{array}{l}\text { st-operativ } \\
\text { prevalenc } \\
\text { gories for }\end{array}$ & $\begin{array}{l}\text { houlder stiffne } \\
\text { the given time } \\
\text { isalata questiol }\end{array}$ & $\begin{array}{l}\text { oint (i.e. t } \\
\text { haire [36]: }\end{array}$ & $\begin{array}{l}\text { umber of } \\
\text { one, } 1=\text { little, }\end{array}$ \\
\hline
\end{tabular}

\section{Study design and outcome}

Two studies were prospectively conducted [26,34]. Four studies defined POSS based on range of motion parameters yet with different thresholds used [25, 26, 34, 35]. Resulting from the analysis of large registry databases, two studies defined POSS as an event requiring manipulation under anesthesia. However, the indication for such manipulation was not defined [23, 24]. One study used the responses to a single question of the L'Insalata questionnaire [36] describing the perceived POSS [22]. POSS event rate ranged between $0.51 \%$ [35] and $8.75 \%$ [26] within a time period ranging from 6 months [22, 34, 35] to 24 months [25].

\section{Statistical analysis methods}

Three studies conducted a multivariable analysis using logistic regression models, specified with factors identified in the literature [24], chosen by the authors themselves [23], or with factors significantly associated with the outcome in the univariable analysis [34].

The four other studies reported a univariable or a bivariable analysis without considering potential confounding, using standard tests to compare groups (Fisher's exact test or Chi-square test) [25, 26, 35] or a subject analysis of variance [22].

\section{Prognostic factor findings - results of individual studies}

Overall, 22 potential prognostic factors were identified (see Table 3). Socio-demographic factors (such as age or sex), comorbidities (like body mass index (BMI), smoking status, diabetes, or hypothyroidism), or injury characteristics (traumatic onset), investigated in at least two different studies, are presented below in separate sections (see Additional file 3). Other factors that were reported in only one study, respectively, are presented in the section "other factor". 
Table 3

summary of prognostic factors findings for the occurrence of post-operative shoulder stiffness

\begin{tabular}{|lll|}
\hline $\begin{array}{l}\text { Factor } \\
\text { category }\end{array}$ & $\begin{array}{l}\text { Probably } \\
\text { prognostic }\end{array}$ & Requiring further analyses \\
\hline $\begin{array}{l}\text { Patient- } \\
\text { related }\end{array}$ & $\begin{array}{l}\text { Age [24, } \\
\text { 34], Sex } \\
\text { [24, 26, }\end{array}$ & $\begin{array}{l}\text { BMI [24, 34], Chronic pulmonary disease [34], Depression or anxiety [34], Diabetes [24, 25, 34, } \\
\text { 35y,lipidemia [34], Gastroesophageal reflux disease [34], Hyper/hypo-thoiroidism [34], } \\
\text { Hypercholesterolemia [34], Hypertension [34], Relatives with diabetes [34], Relatives with } \\
\text { shoulder stiffness [34], Smoking status [24, 34], Vitamin D deficiency [23] }\end{array}$ \\
$\begin{array}{l}\text { Disease- } \\
\text { related }\end{array}$ & $\begin{array}{l}\text { Dominance affected side [34], Preoperative shoulder stiffness [34], Systematic lupus } \\
\text { erythematosus [24], Tear size [34], Traumatic onset [22] }\end{array}$ \\
\hline $\begin{array}{l}\text { Procedure } \\
\text { related }\end{array}$ & Symptom duration [22] \\
\hline
\end{tabular}

\section{Age}

Increased age emerged as a protective factor against POSS, with an association reported in two independent multivariable analyses [24, 34]. Yet, authors used different ways to handle this factor, either dichotomized $(O R=0.5[0.4 ; 0.6]$ for POSS occurrence in the group of patients over 50 years old) [24] or kept continuous (OR $=0.9[0.8 ; 0.9]$ for POSS occurrence with age increases by one year unit) [34]).

\section{Body Mass Index (BMI)}

None of the two studies assessing BMI as a factor did report a significant association with POSS $(\mathrm{OR}=0.7[0.37 ; 1.41]$ for underweight vs. no underweight and $O R=1.12[0.9 ; 1.4]$ for overweight vs. no overweight [24], or $p=0.114$ in univariable analysis [34]). There is currently no evidence supporting an association of BMI with the occurrence of POSS.

\section{Diabetes}

Reported results regarding the association between diabetes and the occurrence of POSS were inconsistent and the prognostic value of diabetes was unclear. One study reported that type I diabetes was significantly associated with POSS (OR $=2.7$ [2.0 ;

3.7]) [24], whereas type II diabetes was not $(\mathrm{OR}=0.9[0.7 ; 1.1])$ [24]. None of the three studies with univariable analyses reported a significant univariable testing $(p>0.254)[25,34,35]$.

\section{Male sex}

Male sex emerged as a probable protective factor against the occurrence of POSS, as its reported associations were consistent in two multivariable analyses $[24,34](\mathrm{OR}=0.5[0.4 ; 0.6]$ and $\mathrm{OR}=0.1[0.0 ; 0.6]$ for male sex $)[24,34]$. An independant univariable analysis, however, did not reach statistical significance $(p=0.205)$ [26].

\section{Hypothyroidism}

The prognostic value of hypothyroidism remained unclear, as only one study reported that hypothyroidism was significantly associated with a higher risk of POSS $[24](\mathrm{OR}=1.3[1.1 ; 1.6])$, whereas the other univariable analysis did not reach statistical significance $(p>0.5)$ [34].

\section{Smoking}

The prognostic value of smoking status remained unclear, as the results of a multivariable analysis indicated that smoking was significantly associated with a lower risk of POSS (OR $=0.5[0.36 ; 0.63])[24]$ and in the other study, the univariable analysis was not statistically significant $(p=0.091)$ [34].

\section{Other factors}

Concomitant comorbidities (such as gastroesophageal reflux disease, systematic lupus erythematosus, vitamin D deficiency) were found to be prognostic factors associated with a higher risk of occurrence of POSS, yet with different statistical analyses 
$[23,24,34]$. A traumatic onset compared to degenerative tears was found to be associated with an increased risk of POSS [22]. The association between symptom duration and the risk of POSS was statistically significant, but the direction of this association was not reported [22].

\section{Quality of evidence}

The quality of the evidence of our results was low (for increased age, male sex) or very low (for the other 20 prognostic factors), mostly due to the small number of included studies and inconsistencies across reported prognostic factor estimates (diabetes, smoking, hypothyroidism, etc.) (see Additional file 4).

\section{Risk of bias within studies}

All included studies suffered from a high overall risk of bias, resulting from being judged at a high risk of bias in at least one of six bias domains (Table 4). Regarding individual bias domains, all included studies suffered from a moderate or a high risk of bias regarding study participation. A lack of clear description of the investigated prognostic factors impacted two studies [24, 34]. Only two studies addressed potential confounding by including factors in their final multivariable models identified in the literature $[23,24]$. Only one study reported both univariable and multivariable effect estimates for all the prognostic factors examined [24].

Table 4

risk of bias of included studies

\begin{tabular}{|c|c|c|c|c|c|c|c|c|}
\hline Author & Year & $\begin{array}{l}\text { Study } \\
\text { participation }\end{array}$ & $\begin{array}{l}\text { Study } \\
\text { attrition }\end{array}$ & $\begin{array}{l}\text { Prognostic } \\
\text { Factor } \\
\text { measurement }\end{array}$ & $\begin{array}{l}\text { Outcome } \\
\text { measurement }\end{array}$ & $\begin{array}{l}\text { Study } \\
\text { confounding }\end{array}$ & $\begin{array}{l}\text { Statistical } \\
\text { analysis } \\
\text { and } \\
\text { reporting }\end{array}$ & $\begin{array}{l}\text { Overall } \\
\text { risk of } \\
\text { bias }\end{array}$ \\
\hline Cho, C.H. & 2015 & High & Low & Low & Low & High & High & High \\
\hline Cho, N.S. & 2015 & Moderate & High & Low & Moderate & High & High & High \\
\hline Tan, M. & 2016 & Moderate & Moderate & Moderate & High & High & High & High \\
\hline $\begin{array}{l}\text { Burrus, } \\
\text { M.T }\end{array}$ & 2019 & Moderate & Moderate & High & Low & Low & Moderate & High \\
\hline $\begin{array}{l}\text { Harada, } \\
\text { G.K. }\end{array}$ & 2019 & High & High & Moderate & Low & Low & High & High \\
\hline Cucchi, D. & 2020 & Moderate & Low & High & High & High & High & High \\
\hline $\begin{array}{l}\text { Takahashi, } \\
\text { R. }\end{array}$ & 2020 & High & High & Moderate & Moderate & High & High & High \\
\hline
\end{tabular}

\section{Analyses of the set of factors specifying multivariable models}

Three studies presented a set of prognostic factors to be considered in multivariable models (Table 5) [23, 24, 34]. Age and sex were found in all these sets. However, the authors included different comorbidities in their final models [23, 24, 34]. The selection process was different in the three studies. One study was fully data-driven [34], whereas the two other studies prespecified their models [23, 24], with one study using the existing literature [24]. 
set of factors of multivariable models

\begin{tabular}{|c|c|c|c|}
\hline Author & Year & Set of factors & $\begin{array}{l}\text { Selection } \\
\text { process }\end{array}$ \\
\hline $\begin{array}{l}\text { Cucchi, } \\
\text { D. }\end{array}$ & 2020 & Age, sex, presence of gastroesophageal reflux disease, and depression and anxiety & $\begin{array}{l}\text { Factors } \\
\text { significant } \\
\text { in } \\
\text { univariable } \\
\text { analysis }\end{array}$ \\
\hline $\begin{array}{l}\text { Burrus, } \\
\text { M.T. }\end{array}$ & 2019 & $\begin{array}{l}\text { Age, sex, body mass index, tobacco use, diabetes, thyroid disorders and systematic } \\
\text { lupus erythematosus. Control of several comorbidities (alcohol use, depression, } \\
\text { hyperlipidemia, hypertension, peripheral vascular disease, coronary artery disease, } \\
\text { congestive heart failure, chronic kidney disease, current hemodialysis use, and chronic } \\
\text { lung disease) }\end{array}$ & $\begin{array}{l}\text { Pre- } \\
\text { specification } \\
\text { of the } \\
\text { model, using } \\
\text { existing } \\
\text { literature }\end{array}$ \\
\hline $\begin{array}{l}\text { Harada, } \\
\text { G.K. }\end{array}$ & 2019 & Age, sex, Charlson Comorbity Index and vitamin D levels & $\begin{array}{l}\text { Not } \\
\text { precisely } \\
\text { described }\end{array}$ \\
\hline
\end{tabular}

\section{Meta-analysis and risk of bias across studies}

Considering the small number of included studies in the present review, we could not perform meta-analysis, evaluate the risk of bias across studies, or conduct any additional subgroup analysis.

\section{Discussion}

Twenty-two potential prognostic factors for POSS after ARCR were identified in the present review. The best available evidence pointed to increased age and male sex as probable prognostic factors decreasing the risk of occurrence of POSS. Associations of various comorbidities such as diabetes, hypothyroidism, and BMI and smoking status with POSS were also reported but do require further analyses to determine their prognostic value.

Our findings with regard to the low methodological quality of included studies were consistent with previous systematic reviews [7, 12]. Of note, older age (more than 50 years old) was already found to be a protective factor for the occurrence of POSS [31]. Nevertheless, this association is still puzzling. On the one hand, older patients tend to have larger tears, for which repairs are thought to be prone to increased initial joint tightness [37], possibly also due to reduced initial tendon length [38]. Repair of larger and more retracted tears may also require advanced surgical dissection that is believed to trigger postoperative fibrosis. On the other hand, repairs of smaller and partial rotator cuff tears - which occur more frequently in younger patients, have been shown to be associated with a higher rate of POSS in previous studies [39]. The high incidence of preoperative rotator interval fibrosis observed in partial tears may partly explain this association [40]. The protective effect of male sex has also been previously identified in investigations on primary adhesive capsulitis [41-43]. Testosterone may inhibit the transforming growth factor beta signaling pathway, which mediates capsular contractions and adhesions seen in POSS [44].

Knowledge of prognostic factors for POSS may help clinicians to tailor patient-specific rehabilitation schemes, e.g. female and younger patients may benefit from limited immobilization [45] and more rapid rehabilitation strategies [46] in the postoperative period. Liberal use of postoperative steroid injections may also be considered in these patients [47].

\section{Limitations}

The well-known lack of a universal definition of POSS [48] limited the interpretation of our results, as various outcome definitions were used (event requiring manipulation under anesthesia, range of motion parameters, and perceived shoulder stiffness) measured at different endpoints (ranging from 6 months up to 24 months). Regarding the statistical analysis, interpretation of our results suffered from the lack of proper multivariable analyses and reports, usually ensuring that a factor has a relevant prognostic value while considering a pre-specified set of factors already known as confounders [6]. 


\section{Conclusions}

Male sex and increased age emerged from the present review as probable prognostic factors decreasing the risk of POSS after ARCR. Additional factors like BMI, smoking status, or comorbidities (diabetes, hypothyroidism) were reported but do require further analyses to draw conclusions regarding their prognostic value. To establish a reliable pre-specified set of factors for CPM predicting POSS, our review results do need to be complemented with an expert's opinion.

\section{Abbreviations}

ARCR Arthroscopic Rotator Cuff Repair

CHARMS-PF Checklist for Critical Appraisal and data extraction for systematic reviews of prediction modeling studies for prognostic factors

CPM Clinical Prediction Model

DMT Diabetes Mellitus Type

PRISMA Preferred Reporting Items for Systematic Review and Meta-Analysis

POSS Post-operative Shoulder Stiffness

QUIPS Quality in prognosis study

US Ultrasound

MRI Magnetic Resonance Imaging

\section{Declarations}

\section{Ethics approval and consent to participate}

Not applicable

\section{Consent for publication}

Not applicable

\section{Availability of data and materials}

The electronic database used to extract the data from individual studies and the code associated with the design of the tables will be uploaded on a GitHub repository once the systematic review for the other outcomes as described on PROSPERO will be completed [49].

\section{Competing interests}

The authors declare they have no competing interests.

\section{Funding}

This literature search is supported by the Swiss National Science Foundation Grant ID 320030_184959 /1.

\section{Authors' contributions}


LA and AMM were the initiators and project leaders. LA, AMM, TS, SA and CAH were involved in the study design. CAH was in charge of the literature search. SA reviewed and commented on the review methodology and statistics. TS coordinated and implemented the review along with LM, RL and ML. LA and TS developed and managed the review database for reference selection and data extraction. While LM and TS performed the study selection, LM, RL, ML and TS extracted study data. TS performed the analysis and prepared the manuscript along with LM. SA brought comments on the relevance of the results from a statistician perspective. $L M, A M M, R L$ and $M L$ brought clinician expertise for the interpretation of the results. All authors reviewed and approved the final version of the manuscript.

\section{Acknowledgments}

The authors acknowledge the support of Dr. Melissa Wilhelmi, medical writer at Schulthess Klinik, Zurich, Switzerland, for manuscript proof-reading and of Dr. Martina Gosteli at University Library, Zurich, Switzerland, and Hannah Ewald at University Medical Library, Basel, Switzerland, for the drafting and peer-reviewing of the search strategies, respectively.

\section{References}

1. Cole BJ, Cotter EJ, Wang KC, Davey A. Patient Understanding, Expectations, and Satisfaction Regarding Rotator Cuff Injuries and Surgical Management. Arthroscopy. 2017 Aug;33(8):1603-1606.

2. Müller AM, Flury M, Alsayed HN, Audigé L. Influence of patient and diagnostic parameters on reported retear rates after arthroscopic rotator cuff repair. Knee Surg Sports Traumatol Arthrosc. 2017 Jul;25(7):2089-2099.

3. Randelli P, Spennacchio P, Ragone V, Arrigoni P, Casella A, Cabitza P. Complications associated with arthroscopic rotator cuff repair: a literature review. Musculoskelet Surg. 2012 Jun;96(1):9-16.

4. Felsch Q, Mai V, Durchholz H, Flury M, Lenz M, Capellen C, Audigé L. Complications Within 6 Months After Arthroscopic Rotator Cuff Repair: Registry-Based Evaluation According to a Core Event Set and Severity Grading. Arthroscopy. 2021 Jan;37(1):50-58.

5. Longo UG, Ciuffreda M, Locher J, Buchmann S, Maffulli N, Denaro V. The effectiveness of conservative and surgical treatment for shoulder stiffness: a systematic review of current literature. Br Med Bull. 2018 Sep 1;127(1):111-143.

6. Steyerberg EW. Clinical prediction models. 2nd edition. Springer; 2019.

7. Fermont AJ, Wolterbeek N, Wessel RN, Baeyens JP, de Bie RA. Prognostic factors for successful recovery after arthroscopic rotator cuff repair: a systematic literature review. J Orthop Sports Phys Ther. 2014 Mar;44(3):153-63.

8. Khair MM, Lehman J, Tsouris N, Gulotta LV. A Systematic Review of Preoperative Fatty Infiltration and Rotator Cuff Outcomes. HSS J. 2016 Jul;12(2):170-6.

9. Lambers Heerspink FO, Dorrestijn O, van Raay JJ, Diercks RL. Specific patient-related prognostic factors for rotator cuff repair: a systematic review. J Shoulder Elbow Surg. 2014 Jul;23(7):1073-80.

10. McElvany MD, McGoldrick E, Gee AO, Neradilek MB, Matsen FA 3rd. Rotator cuff repair: published evidence on factors associated with repair integrity and clinical outcome. Am J Sports Med. 2015 Feb;43(2):491-500.

11. Raman J, Walton D, MacDermid JC, Athwal GS. Predictors of outcomes after rotator cuff repair-A meta-analysis. J Hand Ther. 2017 Jul-Sep;30(3):276-292.

12. Saccomanno MF, Sircana G, Cazzato G, Donati F, Randelli P, Milano G. Prognostic factors influencing the outcome of rotator cuff repair: a systematic review. Knee Surg Sports Traumatol Arthrosc. 2016 Dec;24(12):3809-3819.

13. Page M J, McKenzie J E, Bossuyt P M, Boutron I, Hoffmann T C, Mulrow C D et al. The PRISMA 2020 statement: an updated guideline for reporting systematic reviews. BMJ. 2021; 372 :n71.

14. Denard PJ, Burkhart SS. The evolution of suture anchors in arthroscopic rotator cuff repair. Arthroscopy. 2013 Sep;29(9):1589-95.

15. Erasmus University Medical Centre. Macros for translation of search strategies in bibliographic databases. 2021. http://www.stationsweb.nl/emcmb_cursus/bestanden/macros.html. Accessed 21 Jun 2021. 
16. Bond University Centre for Research in Evidence-Based Practice. Systematic Review Accelerator Polyglot application project. https://sr-accelerator.com/\#/polyglot. Accessed 21 Jun 2021.

17. Bramer WM, Giustini D, de Jonge GB, Holland L, Bekhuis T. De-duplication of database search results for systematic reviews in EndNote. J Med Libr Assoc. 2016 Jul;104(3):240-3.

18. Moons KG, de Groot JA, Bouwmeester W, Vergouwe Y, Mallett S, Altman D et al. Critical appraisal and data extraction for systematic reviews of prediction modelling studies: the CHARMS checklist. PLoS Med. 2014 Oct 14;11(10):e1001744.

19. Hayden JA, van der Windt DA, Cartwright JL, Côté P, Bombardier C. Assessing bias in studies of prognostic factors. Ann Intern Med. 2013 Feb 19;158(4):280-6.

20. Riley RD, van der Windt D, Croft P, Moons KG. Prognosis research in healthcare: concepts, methods, and impact. Oxford University Press; 2019.

21. Huguet A, Hayden JA, Stinson J, McGrath PJ, Chambers CT, Tougas ME et al. Judging the quality of evidence in reviews of prognostic factor research: adapting the GRADE framework. Syst Rev. 2013 Sep 5;2:71.

22. Tan M, Lam PH, Le BT, Murrell GA. Trauma versus no trauma: an analysis of the effect of tear mechanism on tendon healing in 1300 consecutive patients after arthroscopic rotator cuff repair. J Shoulder Elbow Surg. 2016 Jan;25(1):12-21.

23. Harada GK, Arshi A, Fretes N, Formanek B, Gamradt S, McAllister DR et al. Preoperative Vitamin D Deficiency Is Associated With Higher Postoperative Complications in Arthroscopic Rotator Cuff Repair. J Am Acad Orthop Surg Glob Res Rev. 2019 Jul 3;3(7):e075.

24. Burrus MT, Diduch DR, Werner BC. Patient-related Risk Factors for Postoperative Stiffness Requiring Surgical Intervention After Arthroscopic Rotator Cuff Repair. J Am Acad Orthop Surg. 2019 Apr 1;27(7):e319-e323.

25. Cho NS, Moon SC, Jeon JW, Rhee YG. The influence of diabetes mellitus on clinical and structural outcomes after arthroscopic rotator cuff repair. Am J Sports Med. 2015 Apr;43(4):991-7.

26. Cho CH, Ye HU, Jung JW, Lee YK. Gender Affects Early Postoperative Outcomes of Rotator Cuff Repair. Clin Orthop Surg. 2015 Jun;7(2):234-40.

27. Jordan RW, Bentick K, Saithna A. Transtendinous repair of partial articular sided supraspinatus tears is associated with higher rates of stiffness and significantly inferior early functional scores than tear completion and repair: A systematic review. Orthop Traumatol Surg Res. 2018 Oct;104(6):829-837.

28. Pons-Villanueva J, Escalada San Martín J. The stiff shoulder in diabetic patients. Int J Rheum Dis. 2016 Dec;19(12):12261236.

29. Itoi E, Arce G, Bain GI, Diercks RL, Guttmann D, Imhoff AB, Mazzocca AD, Sugaya H, Yoo YS. Shoulder Stiffness: Current Concepts and Concerns. Arthroscopy. 2016 Jul;32(7):1402-14.

30. Cucchi D, Marmotti A, De Giorgi S, Costa A, D'Apolito R, Conca M, Russo A, Saccomanno MF, de Girolamo L; SIGASCOT Research Committee. Risk Factors for Shoulder Stiffness: Current Concepts. Joints. 2017 Dec 11;5(4):217-223.

31. Barden B, DiVenere J, Singh H, Mazzocca AD. Postoperative Shoulder Stiffness After Rotator Cuff Repair. In: Itoi E., editors. Shoulder Stiffness. Springer; 2015.

32. Sabzevari S, Kachooei AR, Giugale J, Lin A. One-stage surgical treatment for concomitant rotator cuff tears with shoulder stiffness has comparable results with isolated rotator cuff tears: a systematic review. J Shoulder Elbow Surg. 2017 Aug;26(8):e252-e258.

33. Audigé L, Blum R, Müller AM, Flury M, Durchholz H. Complications Following Arthroscopic Rotator Cuff Tear Repair: A Systematic Review of Terms and Definitions With Focus on Shoulder Stiffness. Orthop J Sports Med. 2015 Jun 16;3(6):2325967115587861.

34. Cucchi D, Menon A, Feroldi FM, Boerci L, Randelli PS. The presence of gastroesophageal reflux disease increases the risk of developing postoperative shoulder stiffness after arthroscopic rotator cuff repair. J Shoulder Elbow Surg. 2020 Dec;29(12):2505-2513.

35. Takahashi R, Kajita Y, Harada Y, Iwahori Y, Deie M. Clinical results of arthroscopic rotator cuff repair in diabetic and nondiabetic patients. J Orthop Sci. 2021 Mar;26(2):213-218.

Page 15/17 
36. L'Insalata JC, Warren RF, Cohen SB, Altchek DW, Peterson MG. A self-administered questionnaire for assessment of symptoms and function of the shoulder. J Bone Joint Surg Am. 1997 May;79(5):738-48.

37. Hatta T, Giambini H, Hooke AW, Zhao C, Sperling JW, Steinmann SP, Yamamoto N, Itoi E, An KN. Comparison of Passive Stiffness Changes in the Supraspinatus Muscle After Double-Row and Knotless Transosseous-Equivalent Rotator Cuff Repair Techniques: A Cadaveric Study. Arthroscopy. 2016 Oct;32(10):1973-1981.

38. Meyer DC, Farshad M, Amacker NA, Gerber C, Wieser K. Quantitative analysis of muscle and tendon retraction in chronic rotator cuff tears. Am J Sports Med. 2012 Mar;40(3):606-10.

39. Huberty DP, Schoolfield JD, Brady PC, Vadala AP, Arrigoni P, Burkhart SS. Incidence and treatment of postoperative stiffness following arthroscopic rotator cuff repair. Arthroscopy. 2009 Aug;25(8):880-90.

40. Inui H, Sashi R, Nobuhara K. Fibrosis in the rotator interval associated with articular vs. bursal side partial-thickness rotator cuff tears. JSES Int. $2020 \mathrm{Jul}$ 22;4(4):900-905.

41. Hand GCR, Carr AJ. Natural history and genetics of frozen shoulder a 1-20 year follow up of 273 patients. Orthopaedic Proceedings. 2005 87-B:SUPP_II, 161-161.

42. White D, Choi H, Peloquin C, Zhu Y, Zhang Y. Secular trend of adhesive capsulitis. Arthritis Care Res (Hoboken). 2011 Nov;63(11):1571-5.

43. Milgrom C, Novack V, Weil Y, Jaber S, Radeva-Petrova DR, Finestone A. Risk factors for idiopathic frozen shoulder. Isr Med Assoc J. 2008;10(5):361-364.

44. Braga M, Bhasin S, Jasuja R, Pervin S, Singh R. Testosterone inhibits transforming growth factor- $\beta$ signaling during myogenic differentiation and proliferation of mouse satellite cells: potential role of follistatin in mediating testosterone action. Mol Cell Endocrinol. 2012 Mar 5;350(1):39-52.

45. Tirefort J, Schwitzguebel AJ, Collin P, Nowak A, Plomb-Holmes C, Lädermann A. Postoperative Mobilization After Superior Rotator Cuff Repair: Sling Versus No Sling: A Randomized Prospective Study. J Bone Joint Surg Am. 2019 Mar 20;101(6):494-503.

46. Silveira A, Luk J, Tan M, Kang SH, Sheps DM, Bouliane M et al. Move It or Lose It? The Effect of Early Active Movement on Clinical Outcomes Following Rotator Cuff Repair: A Systematic Review With Meta-Analysis. J Orthop Sports Phys Ther. 2021 May 15:1-65.

47. Kim IB, Jung DW. An Intra-articular Steroid Injection at 6 Weeks Postoperatively for Shoulder Stiffness After Arthroscopic Rotator Cuff Repair Does Not Affect Repair Integrity. Am J Sports Med. 2018 Jul;46(9):2192-2202.

48. Audigé L, Blum R, Müller AM, Flury M, Durchholz H. Complications Following Arthroscopic Rotator Cuff Tear Repair: A Systematic Review of Terms and Definitions With Focus on Shoulder Stiffness. Orthop J Sports Med. 2015 Jun 16;3(6):2325967115587861.

49. re3data.org: GitHub. Registry of Research Data Repositories. http://doi.org/10.17616/R3559G. Accessed 21 Jun 2021.

\section{Figures}




\section{Records identified through database searching $(n=10772)$}

[Embase $(n=3720)$, Medline (Ovid) $(n=3307)$, Scopus $(n=3745)]$
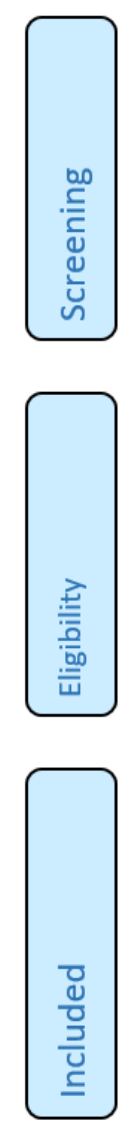

Additional records identified through other sources $(n=8)$

Records after duplicates removed $(n=5013)$
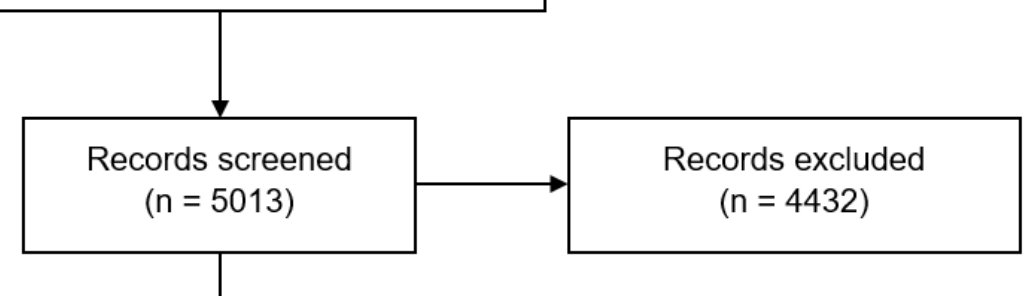

Full-text articles assessed for eligibility $(n=581)$

Full-text articles excluded, with reasons $(n=574)$ :

- No post-operative shoulder stiffness report $(n=293)$

- No factor analysis $(n=$ 120)

- Inadequate study population $(n=39)$

- Inadequate study intervention $(n=57)$

Studies included in quantitative synthesis (meta-analysis)

$$
(\mathrm{n}=0)
$$

- Inadequate study design $(n=5)$

- $\quad$ Follow-up less than 6 months $(n=12)$

- Language other than English, German or French $(n=10)$

- Other reasons (38)

Figure 1

selection flow of included studies (PRISMA 2009 Flow Diagram)

\section{Supplementary Files}

This is a list of supplementary files associated with this preprint. Click to download.

- POSSSRPF20210628Additionalfile1.docx

- POSSSRPF20210628Additionalfile2.docx

- POSSSRPF20210628Additionalfile3.docx

- POSSSRPF20210628Additionalfile4.docx 